\title{
ETHNOBOTANICAL STUDY OF FOOD PLANTS AROUND 'DHEERAA' TOWN, ARSI, ETHIOPIA
}

\author{
Tigist Wondimu, Zemede Asfaw and Ensermu Kelbessa
}

Department of Biology, Faculty of Science, Addis Ababa University

PO Box 1176, Addis Ababa, Ethiopia. E-mail: tigistw22@yahoo.com

\begin{abstract}
A study aimed at identifying plant species used and manipulated by the community for food was carried out around 'Dheeraa' town, in Arsi Zone of Oromia National Regional state, Ethiopia. The data were collected through four round fieldworks conducted from October to December 2003. Random and systematic sampling methods were employed to select the study sites as well as the informants. Ethnobotanical methods using semi-structured interviews were employed to collect data on food plants used by the community. In this study, 71 species of food plants were recorded of which, the local people cultivate 30 species. Wild edible plant species claimed a larger proportion (41 species, 58\%) of the total records. Of the edible plants of the study area 16 species used by the community in traditional medicine, are categorized as nutraceuticals. The non-cultivated food plants are very rare in the area and this might be attributed to the ongoing habitat modification and loss of natural vegetation. It is important to create awareness on sustainable use of wild edibles and the cultivated food. On top of the benefits that these food plants offer as part of the local vegetation, their potentials as food sources are worth considering in efforts towards realizing household food self-sufficiency in the study area.
\end{abstract}

\section{Key words/phrases: Dheeraa, ethnobotany, food plants, indigenous knowledge, nutraceutical plants}

\section{INTRODUCTION}

Depending on their tradition, the people of the world feed upon various types of food. However, $90 \%$ of the food is derived from plant materials and most of these are of high nutritional value. For example, some species of Dioscorea (one of the African traditional food sources) contain almost all nutrients including those normally obtained from animal protein (Baquar, 1992). Fewer than 20 plant species produce $90 \%$ of the food consumed by the global population (Maheshwari, 1987 cited in Maheshwari, 1988). Zemede Asfaw and Mesfin Tadesse (2001) referring to the various sources reported that about $5 \%$ of the total plant species of the world serve as food for human beings. Furthermore, soil protection and improvement, and provision of fuelwood are the indirect roles of plants in increasing the availability of food.

Plants also serve as source of drinking water, which is part of food. The stem and bark of some plant species produce water. For example, a study on useful plants of Ghana by Abbiw (1990) stated that the cut stem of Adansonia digitata, Cleistopholis patens, Costus afer, Phyllanthus muellerianus, Sterculia setigeria produce clear drinking water while Calotropis procera and Daniella oliveri are indicators of underground water. Besides, the water that accumulates in the leaf bases of Ravenala madagascariensis has been mentioned in Willis (1973), for its use as drinking water.

In Ethiopia, there are lots of food materials that are obtained from either cultivated or noncultivated plants. For example, Zemede Asfaw and Mesfin Tadesse (2001) estimated that $8 \%$ of the higher plant species in the country are edible, and $25 \%$ of these are cultivated. Ethiopia has many indigenous food crops (Harlan, 1969; Zemede Asfaw, 1997). Eragrostis tef, Ensete ventricosum, Brassica carinata, Plectranthus punctatus subsp. edulis, Guizotia abyssicica and Coccinia abyssinica are the well-known examples of indigenous crops (Harlan, 1969; IUCN, 1996; Zemede Asfaw, 1997; Zemede Asfaw and Mesfin Tadesse, 2001). The country is also an important center for sorghum, finger millet, field pea and safflower (IUCN, 1996). In addition to the conventional crops, the Ethiopian flora contains many wild plants that produce quantities of food. Hence, the natural vegetation of the wilderness, farmlands and home gardens are sources of edible plants.

This study was conducted in a semi-arid area, which is part of the drylands of Ethiopia. Nabhan and Felger (1985) indicated that arid lands worldwide offer a rich variety of wild and cultivated food plants that have a good adaptation 
to low and variable precipitation regimes. Groove (1985) also mentioned that the arid lands are sources of one fifth of the world's food supplies. According to Maydell (1990), the multipurpose trees of drylands play the best roles in food provision. Nevertheless, environmental crises like global warming, loss of biodiversity and desertification are becoming the major tribulations of human beings. These could also be factors for rising food shortage problems of the world, which is more pronounced in drylands. The prevailing loss of biodiversity calls for collection, investigation and conservation of the natural resources (FAO, 1983). Ethnobotanical information compilation and analysis play vital role in rescuing natural resources of an environment.

This study aims at documenting, describing and studying the utilization and manipulation of the food plants used by the community around 'Dheeraa' town in south-eastern Ethiopia. The study area is an area where environmental degradation is observed and drought and famine frequently affect the people. Hence, studying the food plants available in the surrounding may help to improve the present situation in food shortage and sustainability for the people.

\section{MATERIALS AND METHODS}

\section{Location of the study area}

The study was conducted around 'Dheeraa' town which is located at $8^{\circ} 16^{\prime} \mathrm{N}$ and $39^{\circ} 20^{\prime} \mathrm{E}$ (EMA, 1988), about $125 \mathrm{~km}$ southeast of Addis Ababa. The elevation of the study area is between $1400-1850 \mathrm{~m}$ a.s.l. The altitude increases as one goes from eastern to southwestern and western sides of 'Dheeraa' town. Much of the study area is found in the flat terrain of the Ethiopian Rift Valley and dominated by undulating plains of eastern escarpments (Fig. 1).

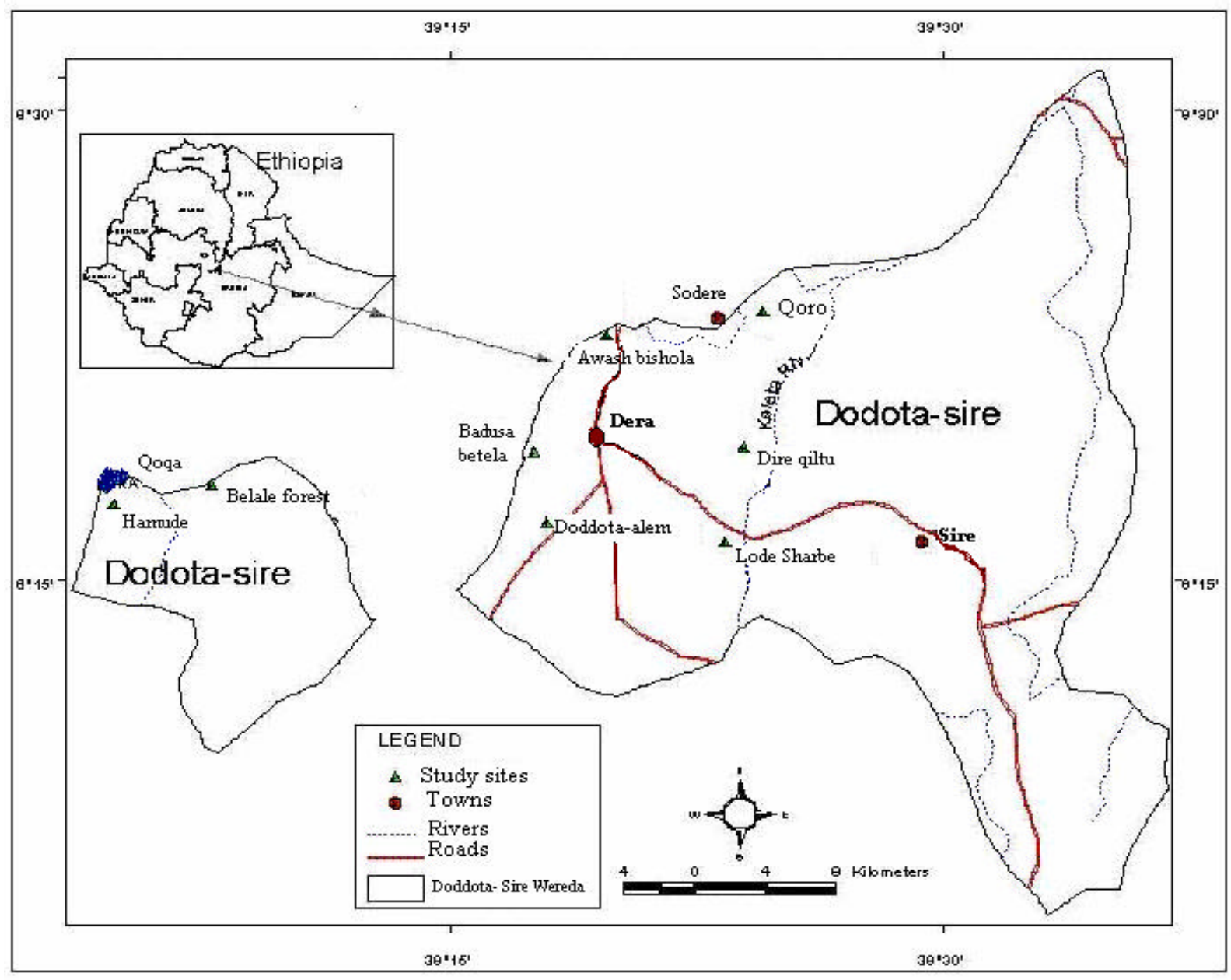

Fig. 1. Map of the study area. 


\section{Climate}

According to the information obtained from Oromiya Bureau of Agricultural Development (OBAD), the average annual rainfall around 'Dheera' is $700 \mathrm{~mm}$, and the shortest and longest rainy seasons are: from February to March, and from June to September, respectively. The hottest season lies between March and June with temperature sometimes exceeding $28^{\circ} \mathrm{C}$. In the coldest season (November to January), the temperature lowers to about $11^{\circ} \mathrm{C}$ and $12^{\circ} \mathrm{C}$. Hence, it lies in the semi-arid climatic zone.

Based on the current agroecological classification (MOA, 1998), the study area lies in three major agroecological zones: SA1 (hot to warm semi-arid lowlands), SA2 (tepid to cool semi-arid midhighlands, and SMR (tepid to cool semi-moist highlands). Specifically, the study sites lie in the sub-agroecological zones of SA1-2 (hot to warm semi-arid lakes and rift valleys), SA2-2 (tepid to cool semi-arid lakes and rift valleys), and SM2-2 (tepid to cool semi-moist lakes and rift valleys).

In MOA (1998), it is indicated that the mean annual percent of evapo-transpiration is 1400-1700 $\mathrm{mm}$, which is greater than the mean annual precipitation (700-1200). This clearly shows that there is moisture deficiency in the area. It is also mentioned in Arsi Zone Food Security Program (2002), that the area usually experiences very erratic rainfall and drought. This together with the high population growth hastens the natural resource degradation.

\section{Vegetation and soil}

The vegetation of the study area belongs to the Somalia-Masai Regional Centre of Endemism (White, 1983). It is characterized by having a flora dominated by Acacia woodland. Cambisol (45\%), Lithosol (35\%) and Adosol (20\%) are the major soil types of the area (MOA, 1998; Arsi Zone Food Security Program, 2002).

\section{Population and land use}

The people are settled farmers growing mainly the annual food crops such as Eragrostis tef, Zea mays and Sorgum bicolor in integration with cattle rearing. Most of them are Afaan-Oromo speakers and some of them speak both Afaan-Oromo and Amharic languages. Based on the information from the District Agricultural Development Office, the total population in the study area is 35,372 with 19,355 males and 16,017 females. About $60 \%$ of the total area is usable; where $46.16 \%, 3.76 \%, 5.37 \%$ and $1.86 \%$ are cultivated, pasture land, natural vegetation and settlement area, respectively.

\section{Sampling techniques and data collection}

The main criterion for the selection of sites was the vegetation cover of the area based on the information obtained from the District Agricultural Development Office as well as the observation during the reconnaissance survey. A total of 75 informants were involved in the study. These informants were selected applying both the systematic and random sampling techniques. The informants were in three age categories (15-25, 2645 , and above 46). Fifteen informants whose ages were more than 40 were considered as key informants and their selection was based on the information obtained from the village leaders.

Ethnobotanical data were collected following Martin (1995), Maundu (1995) and Cunningham (2001). The method of semi-structured interview was applied to obtain information on useful plants. Collection of data was also done through guided field walk, which involves a combination of observation and interview methods. This implies that some of the interviews were made while walking through the vegetation and observing. The vernacular names of the plants were recorded in Afaan-Oromo, except for those indicated otherwise. Informants were also asked to rank and give score to some wild edible plants according to their personal taste and preference.

Plant specimens were collected, pressed and dried in the field. Identification of plant specimens was done in the field and confirmed at the National Herbarium of Ethiopia at Addis Ababa University, where the collected specimens were deposited.

\section{Data analysis}

The data collected through semi-structured interview were analysed using percentages and descriptive statistics like frequency distribution. The scores given to each species as the preference of the informants were added and ranked. The method of cluster analysis was also applied to regroup the responses. This was aided by SPSS version 10.0 software (SPSS, 1999).

\section{RESULTS}

\section{Diversity and status of food plants}

The local community in the study area source edible plant products from agricultural fields, 
home gardens and the natural vegetation. The people in the study area identified 71 species of food plants that they use as food in various ways. These are grouped under 58 genera belonging to 34 families. Forty-one species of these plants are non-cultivated edible plants while the rest are cultivated food plants. The cultivated edible plants are largely herbs while that of the non-cultivated category comprises of largely trees (Table 1). Regarding the parts used as food sources fruits scored the highest number (Table 2).

\section{Cultivated food plants}

Thirty species were documented as cultivated food plants (Appendix 1). Among these, 8 species are fruit crops, 7 species are vegetables, cereals and pulses comprise 5 species, each, 3 species are oil crops and 2 species are cash crops. The largest number for the cultivated plants goes to herbs $(63 \%)$, and the seeds are the most usable parts (19.72\%).

Regarding the family, the Poaceae comprises the largest number ( 6 species), followed by Fabaceae ( 5 species), Asteraceae and Rutaceae 3 species each, Alliaceae and Solanaceae 2 species each, and only 1 species for each of the other families (Appendix 1).

Among the documented cultivated food plants those that are grown in home gardens added up to 15 species $(50 \%)$, those in farmlands were $10(33 \%)$ and the rest 5 species $(17 \%)$ occurred in both farmlands and home gardens.

Though the percentage of cultivated plant species grown in the farmland is fewer as compared to those in the home gardens, the main source of staple food is the farmland. Barley
(Hordium vulgare), wheat (Triticum spp.), maize (Zea mays) and teff (Eragrostis tef) are produced mainly for consumption. Others like pea (Pisum sativum), chickpea (Cicer arietinum), haricot bean (Phaseolus vulgaris), lentil (Lens aulinaris), and linseed (Linum usitatissimum) are produced mainly for the market.

The traditional food of the Arsi Oromo people is porridge made of barley or maize flour. Next to porridge, 'Qamashaa' is the famous traditional food. It is usually prepared from wheat flour. The dough is prepared in a shape of pasta manually or with a simple machine and allowed to dry in sun. Then the required size is taken and cooked whenever needed. This food is served during fasting period and for special guests.

\section{Non-cultivated food plants}

In this study, 41 species of non-cultivated food plants, which belong to 30 genera and 23 families, were collected and enumerated (Appendix 2). This result indicates that wild edible plants of the study area are highly diversified. The fmily Tiliaceae comprises of the largest number of species (6 species), followed by Fabaceae (4 species). Boraginaceae, Moraceae, Anacardiaceae, and Rhamnaceae consist of 3 species each while Appocynaceae and Flacourtiaceae include 2 species each. The other 15 families contain only 1 species each.

Only two of the non-cultivated food plants (5\%) are served after cooking, all the rest (95\%) are eaten raw without any processing. Concerning the parts used, fruits of the non-cultivated food plants are the most frequently used part whereas root, bark and stem are used less frequently (Table 2).

Table 1. Habit and status of food plants.

\begin{tabular}{|c|c|c|c|c|c|c|}
\hline \multirow[t]{2}{*}{ Habit } & \multicolumn{2}{|c|}{ Cultivated } & \multicolumn{2}{|r|}{ Non-cultivated } & \multirow{2}{*}{ Total } & \multirow{2}{*}{$\begin{array}{l}\text { Percent } \\
\text { of total }\end{array}$} \\
\hline & & & & $\%$ & & \\
\hline Herb & 19 & 63.33 & 2 & 4.89 & 21 & 29.6 \\
\hline Shrub & 0 & 0 & 10 & 24.39 & 10 & 14.08 \\
\hline Tree & 8 & 26.67 & 28 & 68.29 & 36 & 50.7 \\
\hline Liana & 1 & 3.33 & 1 & 2.43 & 2 & 2.82 \\
\hline Bulbous & 2 & 6.67 & 0 & 0 & 2 & 2.82 \\
\hline Total & 30 & 100 & 41 & 100 & 71 & 100 \\
\hline
\end{tabular}

Table 2. Parts of plant used as food.

\begin{tabular}{lllllllll}
\hline & Root & Stem & Leaf & Fruit & Seed & Bark & Bulb & Gum \\
\cline { 2 - 8 } Cultivated & 0 & 1 & 2 & 11 & 14 & 0 & 2 & 0 \\
Non-cultivated & 1 & 1 & 2 & 35 & 0 & 1 & 0 & 2 \\
Total & 1 & 2 & 4 & 46 & 14 & 1 & 2 & 2 \\
\hline Percent of total & 1.41 & 2.82 & 5.63 & 64.79 & 19.72 & 2.82 & 2.82 & 2.82 \\
\hline
\end{tabular}


Youngsters and children were observed using wild edible plants more frequently than the other age groups. Hence, this group of the community was able to tell all the names of the wild edible plants and the parts used. They were the sole informants about Capparis fascicularis (Haarangamaa-adii), Erythrina brucei (Waleenaa), Scutia myrtina (Budagaree), Toddalia asiatica (Arabagubee), and Ziziphus spina-christi (Buleesaa).

The key informants were asked to rank 6 species of wild edible plants for their good taste according to their personal preference. The scores given to each species were added and the highest score was ranked to be first. Accordingly, Balanites aegyptiaca ranked first (Table 3). Most of the informants tasted and confirmed that they are familiar with the fruit. Cluster analysis was made to confirm this result and the degree of similarity between the responses of informants is shown in Figure 2.

\section{Nutraceutical plants}

Among the species recorded in this study, about 16 species benefit the community in two ways; providing food as well as traditional medicine. Further analysis showed that 5 of the species were cultivated (4 species in home gardens and one species in farmland) and the other 11 species were non-cultivated food plants. The nutraceutical species recorded in this study are given in Table 4 along with their medicinal uses.

Table 3. Preference ranking for most popular non-cultivated food plants.

\begin{tabular}{|c|c|c|c|c|c|c|}
\hline \multirow{2}{*}{$\begin{array}{c}\text { Scores given by key } \\
\text { informants } \\
\text { (respondents) }\end{array}$} & \multicolumn{6}{|c|}{ Species name } \\
\hline & $\begin{array}{l}\text { Balanites } \\
\text { aegyptiaca }\end{array}$ & $\begin{array}{l}\text { Ficus } \\
\text { sycomorus }\end{array}$ & $\begin{array}{l}\text { Grewia } \\
\text { bicolor }\end{array}$ & $\begin{array}{l}\text { Mimusops } \\
\text { kumel }\end{array}$ & $\begin{array}{l}\text { Rhus } \\
\text { natalensis }\end{array}$ & $\begin{array}{l}\text { Ziziphus } \\
\text { mucronata }\end{array}$ \\
\hline R1 & 6 & 3 & 5 & 1 & 2 & 4 \\
\hline $\mathrm{R} 2$ & 6 & 2 & 4 & 3 & 1 & 5 \\
\hline R3 & 5 & 3 & 4 & 1 & 2 & 6 \\
\hline R4 & 6 & 3 & 2 & 4 & 1 & 5 \\
\hline $\mathrm{R} 5$ & 6 & 3 & 2 & 4 & 1 & 5 \\
\hline R6 & 6 & 3 & 2 & 4 & 1 & 5 \\
\hline R7 & 6 & 4 & 2 & 3 & 1 & 5 \\
\hline R8 & 6 & 3 & 2 & 4 & 1 & 5 \\
\hline R9 & 6 & 2 & 5 & 1 & 3 & 4 \\
\hline R10 & 6 & 2 & 4 & 1 & 3 & 5 \\
\hline R11 & 6 & 2 & 4 & 1 & 3 & 5 \\
\hline R12 & 6 & 3 & 2 & 4 & 1 & 5 \\
\hline R13 & 6 & 2 & 4 & 1 & 3 & 5 \\
\hline R14 & 6 & 3 & 2 & 4 & 1 & 5 \\
\hline R15 & 6 & 2 & 4 & 1 & 3 & 5 \\
\hline Total score & 89 & 40 & 48 & 37 & 27 & 74 \\
\hline Rank & 1 & 4 & 3 & 5 & 6 & 2 \\
\hline
\end{tabular}

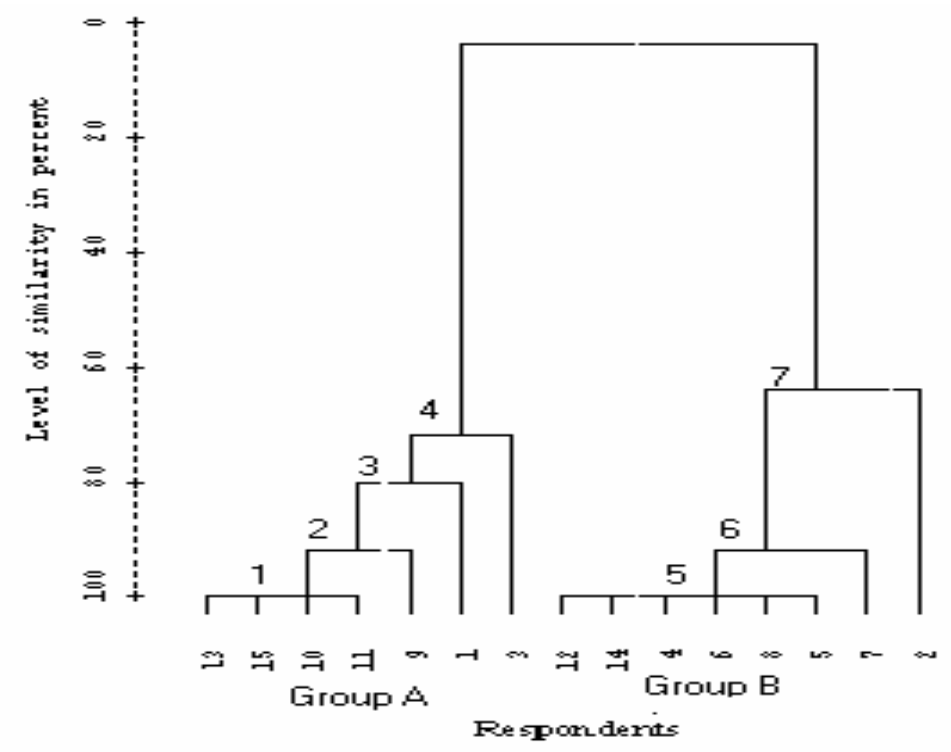

Fig. 2. Dendrogram showing the similarity of responses to the most important Non-Cultivated Food Plants. 
Table 4. List of species with nutraceutical values.

\begin{tabular}{lll}
\hline Species name & Parts used & Used to treat \\
\hline Allium sativum & Bulb & Flue, and lung abscess \\
Balanithes aegyptiaca & Gum & Feverile disease \\
Capparis fascicularis & Root & Tooth ache and wounds \\
Carica papaya & Seed and Fruit & Diarrhoea \\
Carisa spinarium & Root & - Stomach ache and muscle cramp \\
& Stem & - Evil eye \\
Citrus aurantifolia & Fruit & Flue, wounds, stomach ache, skin rush \\
Cordia ovalis & Leaf and Stem & Feverile disease \\
Cucurbita pepo & Seed & Stomach ache (worm expulsion) \\
Grewia bicolor & Leaf & Stomach ache \\
G. ferruginea & Leaf & Stomach ache \\
G. villosa & Leaf & - Stomach ache \\
& Stem & - Allergies that make the body swell \\
Opuntia ficus-indica (L.) Miller & Fruit & Gastritis \& Diarrhoea \\
Papea capensis & bark & Tonsillitis \\
Punica granatum & Leaf & Diarrhoea \\
Rumex nervosus & Leaf & - Diarrhoea \\
Ximenia americana & Root & - Wound \& Hepatitis \\
\hline
\end{tabular}

Note: For the uses of these plants as food, see Appendix 1 and 2.

\section{DISCUSSION}

The food plant species recorded in this study comprised of the cultivated food plants and the non-cultivated edible plants; the former being categorized as conventional food crops and the latter as wild or semi-wild food plants. Similar categorization was made by Zemede Asfaw (1997) in his study of the useful plants of Ethiopia.

Although larger number of species than those grown in fields is grown in home gardens, home gardening is not adequately practiced in the study area. Part of the reason for this may be related to the shortage of water sources in the area. However, the results indicate that traditional people work hard to harmonize their environment by planting many species of plants with various uses. This is usually practiced in their home gardens. Hence, the home gardens similar to other traditional home gardens in the country mentioned by Zemede Asfaw (1997), house diverse species of plants.

Very rare plant species of the area were encountered in these poorly developed gardens. This corroborates with earlier results which reported that home gardens serve as refuges for endangered useful species. Similar to most parts of the country (e.g., Zemede Asfaw, 1997), the home gardens in the study sites are located in close association with living houses, composed mainly of food plants.

The gardens provide plant materials for quick and easy access to foodstuffs, like maize (Zea mays), haricot bean (Phaseolus vulgaris), tomato (Lycopersicon esculentum), pepper (Capsicum annuum), sugarcane (Saccharum officinarum), mango (Mangifera indica) and papaya (Carica papaya). These crops are produced in limited numbers for local consumption.

\section{Non-cultivated food plants (wild edible plants)}

More numbers of wild edible plant species were recorded in this study than the cultivated category. However, when the level of use is considered, there is more reliance on the few cultivated food plants. According to the informants, wild edible plants are consumed by households when there is failure in harvest of the cultivated food crops because of drought. At other times children enjoy most wild edible plants. The general public consumes wild edibles as snacks, supplement or refreshments. Therefore, they occasionally consider the wild edible plants as famine foods or foods for children. Similar studies from other parts of the country by Zemede Asfaw (1997) and Tesfaye Aawas (1997) as well as from other parts of the world (e.g., Cunningham, 2001; Grivetti, 2001) reported that wild edible plants help to prevent starvation and sustain life during drought season and social unrest.

The neglect of wild edible plants by the present human beings may end up with a reduction of dietary diversity and knowledge associated with wild edible plants (Grivetti, 2001). The observation 
in the study area shows that the people rely on a very small range of crops as their food source. Regarding the knowledge associated with wild edible plants, the younger people could tell the uses of plants as food than for other uses. As a result more ethnobotanical data about the noncultivated food plants were obtained from male youngsters. This may be because these individuals spend most of their time in more natural areas, herding cattle where they interact with many wild edible plants. Commonly, they take their snack from the gift of the wild vegetation, and rarely go back home for lunch. Staying longer time with the plants might have given them enough time to taste the plants and become familiar to them. Thus, they can identify, tell the names, compare the sweetness, texture, flavor and other characteristics. For example, children of the area very much like to eat the dry fruit of Prosopis juliflora. Though the plant is an alien species recently introduced to the area, they gave it a local name and call it "Yezinjero qitta" which means "bread of baboons". This indicates that the elderly people no longer keep their knowledge about wild edible plants than other use categories such as medicines, construction and fuel wood. This further asserts that wild edible plants are given less worth as food by the elderly people.

The local community use the non-cultivated plants more as medicine, fuel wood and construction material, than as food. Therefore, they are overused and as a result they are not frequently encountered in the area at the present time. The elderly informants have been talking with a great regret about the loss of most of the wild edible plants and most of the time and further affirmed that it is a result of habitat modification. This is also what is happening in other parts of the country namely the Cheffa District in southern Wolo (Bayafers Tamene, 2000). According to the informants the wild edible plant species that are low in population are Mimusops kummel, Ximenia americana, Cordia ovalis, Ziziphus spina-christi, Ziziphus mucronata and Rhus retinorrhoea. Fruits of Mimusops kummel and Ziziphus mucronata are sold in the local market.

As a result of the preference ranking, the fruit of Balanites aegyptiaca was found to be the commonly used and tastier non-cultivated food plant. Most people prefer this plant, may be because it is more abundant than the other species. Hence, it is well known by all age groups of the community.

The analysis employed produced two major clusters of informants (Group 'A' and Group 'B', see Figure 2). The grouping differentiated informants that are from different localities with different plant associations as indicated in Table 5. The two localities are situated on the opposite sides of the center of the study area (Dheeraa) and have different altitudes (between 1400-1700 m a.s.l. for the localities of Group 'A' and between 1800-1850 $\mathrm{m}$ a.s.l. for the localities of Group ' $\mathrm{B}$ '). The vegetation type where the respondents Group ' $\mathrm{A}$ ' are living is dominated by Acacia-Balanites community. The informants in Group 'B' are living in the plant community where Grewia spp. and Rhus spp. are dominant. Respondents who are living in the same village show more similarity in their knowledge than those from other villages. For example: Respondents 13, 15, 10, and 11 from group ' $\mathrm{A}$ ' are residents of the same village and they show $100 \%$ similarities. Similarly, respondents 12, 5 , and 6 from group 'B' are living in the same village and these also show $100 \%$ similarity (Table 5). This can reflect what has been said earlier by Balick and Cox (1996) that traditional societies of the world accumulated a wealth of knowledge as a result of prolonged interaction with the natural world in their surroundings.

Table 5. Clusters of respondents.

\begin{tabular}{lll}
\hline Major Clusters & $\begin{array}{l}\text { Included } \\
\text { Respondents }\end{array}$ & \multicolumn{1}{c}{ Main features } \\
\hline Group 'A' & $13,15,10,11,9,1,3$ & $\begin{array}{l}\text { All respondents are inhabitants of the study sites located } \\
\text { in the western part of 'Dheera' where Grewia spp. and } \\
\text { Rhus spp. are the commonly encountered wild edible } \\
\text { plants } \\
\text { All respondents are inhabitants of the study sites located } \\
\text { in the eastern part of 'Dheera' where Acacia spp. and } \\
\text { Balanites aegyptiaca are the commonly encountered wild } \\
\text { edible plants }\end{array}$ \\
\hline
\end{tabular}




\section{Nutraceutical plants}

The products or by-products of food plants serve human beings in so many ways, one of which is medicine. Food plants that also offer medicine are known as nutraceutical plants. The term nutraceutical implies "food or parts of food that provide medical or health benefits" (Felice, 1999). In this study about $39 \%$ of the nutraceutical plant categories are products of the home gardens as vegetables and fruits. Though the informants mention these food plants as medicine, the community most frequently uses garlic (Allium sativum) and Lemon (Citrus aurantifolia). The use of the former is acknowledged, particularly as a spice and medicine. It is also mentioned in many literature sources being a healer for many diseases (Ferrie, 2003; Felice, 2004). The rest of the nutraceutical category of the study area comprises about $61 \%$ of the total plants giving food and medicine to the community. Among the wild edible plants categorized as nutraceutical plants, those most frequently used by the community are Balanithes aegyptiaca and Carissa spinarum (C. edulis). This might be because these species of plants are more abundant than the other species. In Kabuye and Ngugi (2001), it is shown that Carissa spinarum on top of being eaten is also used by a number of communities in Kenya to strengthen bones and for general fitness. This plant is used for similar applications by the local community to the study area.

\section{CONCLUSION}

The people of the study area use a large number of food plant species. However, the reliance for daily diet is more on the cultivated food crops than on the non-cultivated (wild) edible plants. Wild edible plants are widely used by all age groups only during drought or famine season. The community does not attach credible importance of the plants in their nutritional value.

Some of the food plants studied are also used as medicinal plants. Such benefits of plants as food and medicine can be considered as the best sustenance of life. Therefore, attention should be given to these plants and creating awareness about the benefit of nutraceutical plants may speed up the initiation of conservation of plant resources.

As it is indicated in the literature and mentioned by the informants, deforestation, changes of habitats, environmental degradation and cultural transformation have resulted in loss of the natural vegetation. These in turn become factors for loss of useful plants and the knowledge associated with these plant species. Hence, conservation strategy that allows the participation of the local people may help in rehabilitation of the natural environment. In addition to the general benefits of the food plants as part of the local vegetation, their gross potentials as food and other utilities implicate their importance in realizing household food self-sufficiency in the study area.

\section{ACKNOWLEDGEMENTS}

We would like to acknowledge RPSUD (Regional Programme for Sustainable Use of Dryland Biodiversity) for its financial support. The Arsi Zone of Oromia National Regional State, the Department of Biology, all staff members of the National Herbarium and the informants are thanked for various supports.

\section{REFERENCE}

1. Abbiw, D.K. (1990). Useful Plants in Ghana: West Africa Uses of Wild and Cultivated Plants. Intermediate Technology Publication and the Royal Botanic Gardens, Kew, 337 pp.

2. Arsi Zone Food Security Program (2002). First quarter report on EGS (Employment Generation Scheme) project. Oromia Food Security Program.

3. Balick, J.M. and Cox, P.A. (1996). Plants, People and Culture: The Science of Ethnobotany. Scientific American Library, New York, 228 pp.

4. Baquar, S.R. (1992). Economic importance of yams (Dioscoria spp.) and their natural products with special reference to West Africa. In: The Status of Some Plant Resources in Part of Tropical Africa. Botany 2000. Monograph Series No 2, pp. 19-23, (Edwards, S. and Zemede Asfaw, eds). NAPRECA, Addis Ababa University, Addis Ababa.

5. Bayafers Tamene (2000). A floristic analysis and ethnobotanical study of the semi-wet hnd of Cheffa Area, South Welo, Ethiopia. MSc thesis. Addis Ababa University.

6. Cunningham, A.B. (2001). Applied Ethnobotany. People, Wild Plant Use and Conservation. Earth Scan Publication Ltd. London and Sterling, UNESCO, Royal Botanic Garden, WWF.

7. EMA (1988). National Atlas of Ethiopia. Ethiopian Mapping Authority, Addis Ababa. 
8. FAO (1983). Selected Medicinal Plants. In: FAO Plant Production and Protection Paper 53(1), pp. 1-94. UN, Rome.

9. Felice, M.D.S. (1999). Nutraceutical Research and Education Act, $106^{\text {th }}$ Congress. In: The Foundation for Innovation in Medicin, pp. 1-7. http://www.fimdefelice.org/archives/arc.nrea.html

10. Felice, M.D.S. (2004). Nutraceuticals, functional foods, phytochemicals and health protecting foods. In: Nutraceuticals Cholesterol: Health and Medical Information about High Cholesterol and Heart Disease, pp.1-3. http://www.medicinenet.

11. Ferrie, A.M.R. (2003). Microspore Breeding Programs for Nutraceutical plants. In: Plants that Heal, pp. 1-5. PBI Bulletin, 2003 Issue 1. http://pbiibp.nrc-nrc.gc.ca/en/bulletin/2003issue1/page 5.htm

12. Grivetti, L. (2001). Reading 8: Edible Wild Plants, Part 1 , issued on 8/20/04. http://www.ucdavis.edu $\backslash$ Grivetti.htm

13. Groove, A.T. (1985). The Arid Environment. In: Plant for Arid Lands, pp. 1-8, (Wickens, G.E., Goodin, J.R. and Field, D.V., eds). George Allen \& UNWIN, London.

14. Harlan, J. (1969). Ethiopia: a centre of diversity. Econ. Bot. 23:301-314.

15. IUCN (1996). Plant Resource of Eastern Africa: Activities and Resource of Information, $341 \mathrm{pp}$.

16. Kabuye, C.S. and Ngugi, G.W. (2001). Nutritional and medicinal importance of indigenous food plants. In: The Potential of Indigenous Wild Foods: Workshop Proceedings, pp. 57-60, (Kenyatta, C. and Henderson, A., eds). USAID/OFDA.

17. Maheshwari, J.K. (1988). Ethnobotanical research and documentation. Acta Univ. Symb. Bot. Ups. 28(3):207-217.
18. Martin, G.J. (1995). Ethnobotany: A 'People and Plants' Conservation Manual. Chapman and Hall, London, 268 pp.

19. Maundu, P. (1995). Methodology for collecting and sharing indigenous knowledge: A case study. Indigenous Knowledge and Development Monitor $3(2): 3-5$.

20. Maydell, H.V. (1990). Trees and Shrubs of Sahle: their Characteristics and Uses. GTZ. (Deutsche Gesellscheft fur Technische and Zusammenarbeit. Verlag Josef Margraf, Weikershein), 525 pp.

21. MOA (1998). Agroecological Zones of Ethiopia. Natural Resource Management and Regulatory Department. Ministry of Agriculture, Addis Ababa.

22. Nabhan, G.P. and Felger, R.S. (1985). Wild desert relatives of crops: their direct uses as food. In: Plants of Arid Lands, pp. 243-266, (Wickens, G., Goodin, J. and Field, D., eds). George Allen and Unwin Ltd. London.

23. SPSS (1999). SPSS for Windows. Statistical Software Package, Version 10, sPSS Inc.

24. Tesfaye Aawas (1997). A Study on the ecology and ethnobotany of non-cultivated food plants and wild relatives of cultivated rops in Gambella Region, Southwestern Ethiopia. MSc thesis, Addis Ababa University.

25. White, F. (1983). The Vegetation of Africa. UNESCO, Paris.

26. Willis, J.C. (1973). A Dictionary of Flowering Plants and Ferns. Cambridge University Press, UK.

27. Zemede Asfaw (1997). Indigenous African Food Crops and Useful Plants. Survey of Food Crops, Their Preparations and Home Gardens in Ethiopia. UnU/INRA No. B6, ICIPE. Science Press, Nairobi, $65 \mathrm{pp}$.

28. Zemede Asfaw and Mesfin Tadesse (2001). Prospects for sustainable use and development of wild food plants in Ethiopia. Econ. Bot. 55(1):47-62.

Appendix 1: List of cultivated food plants in the study area.

\begin{tabular}{|c|c|c|c|c|c|}
\hline Scientific name & $\begin{array}{l}\text { Family } \\
\text { name }\end{array}$ & $\begin{array}{l}\text { Vernacular } \\
\text { name }\end{array}$ & Habit & $\begin{array}{l}\text { Parts } \\
\text { used }\end{array}$ & Grown in \\
\hline Allium cepa L. & Alliaceae & Qullubbii-diimaa & Bulbous & Bulb & Farm lands \\
\hline A. sativa L. & Alliaceae & Qullubbii-adii & Bulbous & Bulb & Farm lands \\
\hline Brassica carinata A.Br. & Brassicaceae & Gommana & Herb & Leaf & Farm lands \&home gardens \\
\hline Capsicum annum L. & Solanaceae & Qaaraa & Herb & Fruit & Home gardens \\
\hline Carica papaya L. & Caricaceae & Paappaayee & Tree & Fruit & Home gardens \\
\hline Carthamus tinctorius L. & Asteraceae & Suufii & Herb & Seed & Farm lands \& home gardens \\
\hline Casimiroa edulis La Llave. & Rutaceae & Kasmiroo & Tree & Fruit & Home gardens \\
\hline Cicer arietinum $\mathrm{L}$. & Fabaceae & Shumburaa & Herb & Fruit & Home gardens \\
\hline $\begin{array}{l}\text { Citrus aurantifolia (Christm) } \\
\text { Swingle }\end{array}$ & Rutaceae & Loomii & Tree & Fruit & Home gardens \\
\hline C. sinensis (L.) Obs. & Rutaceae & Burtukaana & Tree & Fruit & Home gardens \\
\hline Coffea arabica L. & Rubiaceae & Buna & Tree & Seed & Home gardens \\
\hline Cucurbita pepo L. & Cucurbitaceae & Dabaaqula & Liana & Fruit & Home gardens \\
\hline
\end{tabular}


Appendix 1 (Contd).

\begin{tabular}{|c|c|c|c|c|c|}
\hline Scientific name & $\begin{array}{l}\text { Family } \\
\text { name }\end{array}$ & $\begin{array}{l}\text { Vernacular } \\
\text { name }\end{array}$ & Habit & $\begin{array}{l}\text { Parts } \\
\text { used }\end{array}$ & Grown in \\
\hline Eragrostis tef (Zucc.) Trontter & Poaceae & Xaafii & Herb & Seed & Farm land \\
\hline Helianthus annus L. & Asteraceae & Suufii-faranjii & Herb & Seed & Farm land \& home garden \\
\hline Hordeum vulgaris L. & Poaceae & Garbuu & Herb & Seed & Farm land \\
\hline Lactuca sativa L. & Asteraceae & Salaaxaa & Herb & Leaf & Home garden \\
\hline Lathyrus satious L. & Fabaceae & Gaayoo & Herb & Seed & Farm land \\
\hline Lens culinaris Medik & Fabaceae & Misira & Herb & Seed & Farm land \\
\hline Linum usitatissimum L. & Linaceae & Talbaa & Herb & Seed & Farm land \\
\hline Lycopersicon esculatum Mill. & Solanaceae & Timaatimii & Herb & Fruit & Home garden \\
\hline Mangifera indica L. & Anacardiaceae & Maangoo & Tree & Fruit & Home garden \\
\hline Musa x paradisiaca L. & Musaceae & Muuzzii & Herb & Fruit & Home garden \\
\hline Phaseolus vulgaris L. & Fabaceae & Boloqqee & Herb & Seed & Farm land \& home garden \\
\hline Pisum sativum L. & Fabaceae & Atara & Herb & Seed & Farm land \\
\hline Psidium guajava L. & Myrtaceae & Zayitunaa & Tree & Fruit & Home garden \\
\hline Punica granatum L & Lythraceae & Romaana & Tree & Fruit & Home garden \\
\hline Saccharum officinarum $L$. & Poaceae & Shonkoraa & Herb & Stem & Home garden \\
\hline Sorghum bicolor (L.) Moench. & Poaceae & Maashingaa & Herb & Seed & Farm land \\
\hline Triticum spp. & Poaceae & Qamadii & Herb & Seed & Farm land \\
\hline Zea mays L. & Poaceae & Bogqooloo & Herb & Seed & Farm land \& home garden \\
\hline
\end{tabular}

Appendix 2: List of non-cultivated food plants.

\begin{tabular}{|c|c|c|c|c|c|}
\hline $\begin{array}{l}\text { Voucher } \\
\text { No. }\end{array}$ & Scientific name & Family name & Vernacular name & Habit & Parts used \\
\hline 052 & Acacia seyal Del. & Fabaceae & Waaccu & Tree & Gum \\
\hline 018 & A. tortilis Harms. & Fabaceae & Xadacha & Tree & Gum \\
\hline 046 & Acokanthera schimperi (A.DC.) Benth. & Appocynaceae & Qaraaruu & Tree & Fruit \\
\hline 033 & Amaranthus graecizans L. & Amaranthaceae & Caameraa & Herb & Leaf \\
\hline 050 & Balanites aegyptiaca (L.) Del. & Balanithaceae & Badanaa & Tree & Fruit \\
\hline 015 & Capparis fascicularis DC. & Capparidaceae & Haarangamaa-aadii & Shrub & Fruit \\
\hline 048 & Carissa spairanum L. (C. edulis) & Appocynaceae & Agamsaa & Shrub & Fruit \\
\hline 127 & Cordia africana Lam. & Boraginaceae & Waddeesaa & Tree & Fruit \\
\hline 027 & C. ovalis R. Br. ex G. Don & Boraginaceae & Mandhera & Tree & Fruit \\
\hline 026 & Dooyalis abyssinica (A. Rich.) Warb. & Flacourtiaceae & Koshmii & Shrub & Fruit \\
\hline 016 & Ehretia cymosa Thonn. & Boraginaceae & Ulaagaa & Tree & Fruit \\
\hline 057 & Erythrina brucei Schweinf. & Fabaceae & Waleenaa & Tree & Root \\
\hline 024 & Ficus sur Forssk. & Moraceae & Habruu & Tree & Fruit \\
\hline 071 & F. sycomorus L. & Moraceae & Odaa & Tree & Fruit \\
\hline 072 & F. vasta Forssk. & Moraceae & Qilxuu & Tree & Fruit \\
\hline 020 & Fluggea virosa (Willd.) Vigot. & Euphorbiaceae & Qacaaculee & Shrub & Fruit \\
\hline 085 & Grewia bicolor Juss. & Tiliaceae & Haaroressa & Tree & Fruit \\
\hline 060 & G. ferruginea Hochst. ex A. Rich & Tiliaceae & Doqono & Tree & Fruit \\
\hline 017 & G. mollis Juss. & Tiliaceae & Haaroressa-arbaa & Tree & Fruit \\
\hline 125 & G.trichocarpa Hoschst. ex A. Rich & Tiliaceae & Gororaa & Tree & Fruit \\
\hline 066 & G. tenax (Forssk.) Fiori & Tiliaceae & Qococee & Shrub & Fruit \\
\hline 051 & G. villosa Willd. & Tiliaceae & Ogobdii & Tree & Fruit \\
\hline 008 & Lannea schimperii (A. Rich.) Engl. & Anacardiaceae & Haandarkoo & Tree & Fruit \\
\hline 082 & Lantana camara L. & Verbenaceae & Yeregna-qolo* & Shrub & Fruit \\
\hline \multirow[t]{2}{*}{091} & Mimusops kumel Bruce ex DC. & Sapotaceae & Olaatii & Tree & Fruit \\
\hline & $\begin{array}{l}\text { Olea europaea L. subsp. cuspidata } \\
\text { (Wall. ex G. Don) Cif., L' Olivicoltore }\end{array}$ & Oleaceae & Ejersa & Tree & Fruit \\
\hline 094 & Oncoba spinosa Forssk. & Flacourtiaceae & Aakuku & Tree & Fruit \\
\hline 126 & Opuntia ficus-indica (L.) Miller & Cactaceae & Aabushuki/ Shonkaa & Shrub & Fruit \\
\hline 059 & Papea capensis Eckl. \& Zeyh. & Sapindaceae & Biiqqaa & Tree & Fruit \\
\hline 096 & Pentarrhinum hispidum E. Mey. & Asclepidiaceae & Gaale & Liana & Fruit \\
\hline 098 & Prosopis juliflora (Sw.) DC. & Fabaceae & Yezinjero-qita* & Tree & Fruit \\
\hline 099 & Rhus natalensis Krauss & Anacardiaceae & Dabobessa & Shrub & Fruit \\
\hline 009 & Rhus retinorrhoea Oliv. & Anacardiaceae & Haawaas/ Dabalucaa & Tree & Fruit \\
\hline 013 & Rumex nervosus Vahl. & Polygonaceae & Dhangaggo & Shrub & Stem \\
\hline 103 & Scutia myrtina (Burm. f.) Kurz. & Rhamnaceae & Budagaree & Tree & Fruit \\
\hline 111 & Sysygium guineense (Willd.) DC. & Myrtaceae & Baddeessa & Tree & Fruit \\
\hline 112 & Tagetes minuta L. & Asteraceae & Ajowaa & Herb & Leaf \\
\hline 124 & Toddalia asiatica (L.) Lam. & Rutaceae & Arrabagubee & Shrub & Fruit \\
\hline 117 & Ximenia americana L. & Olecaceae & Hudaa & Tree & Fruit \\
\hline 061 & Ziziphus mucronata Willd. & Rhamnaceae & Qurquraa & Tree & Fruit \\
\hline 053 & Ziziphus spina-christi (L.) Desf. & Rhamnaceae & Bulessaa & Tree & Fruit \\
\hline
\end{tabular}

* Amharic names. 